KULTURA

i

\title{
DYSKURS AKADEMICKI I PRASOWY NA TEMAT UBÓSTWA NA BIAŁORUSI: KILKA REFLEKSJI
}

Bieda towarzyszy wszystkim społeczeństwom na różnych etapach ich rozwoju, nasila się w okresach przełomowych — kryzysów, kataklizmów, reform. Każde społeczeństwo inaczej traktuje (definiuje, próbuje rozwiązać) ten problem społeczny. W społeczeństwach demokratycznych jest to obszar otwarty do dyskusji dla różnych aktorów społecznych, często rozpatrywany z perspektywy wykraczającej poza ekonomiczne aspekty ubóstwa, z nawiązaniem do praw jednostki, do jej podmiotowości, godności. W społeczeństwach niedemokratycznych ubóstwo staje się tematem ukrytym za zasłoną innych problemów i procesów społecznych. W każdym razie jednak nie da się go ominąć, jest bowiem ważny i dotkliwy, a więc zostaje uwzględniony z zastosowaniem swoistego kodu ograniczonego - w skali makrospołecznej, statystycznie, z położeniem nacisku na sukcesy państwa w polityce społecznej, niekrytycznie lub mało krytycznie w stosunku do prowadzonej polityki społecznej. Niezależnie od typu społeczeństwa problem ubóstwa to zawsze kwestia relacji wiedzy i władzy. To elity symboliczne — mówiąc metaforycznie — rysują pejzaże biedy oraz portrety ludzi biednych. Do elit tych można zaliczyć między innymi badaczy oraz dziennikarzy.

Prasa ma na celu dostarczyć ciekawych tematów, przykuć uwagę czytelników. Naukowcy częściej zajmują się problemami ważnymi niż ciekawymi, starając się przedstawić je w sposób obiektywny lub intersubiektywnie obiektywny. Różne dyskursy rządzą się własnymi prawami. Wiedza, która się wyłania zarówno $z$ dyskursu akademickiego, jak i medialnego (prasowego), służy uzupełnieniu relatywnie całościowego obrazu biedy, na który składa się wiele innych istotnych dyskursów, jak dyskurs pracowników pomocy spo-

Adres do korespondencji: tkanash@aps.edu.pl 
łecznej, dyskurs polityki, a przede wszystkim dyskurs osób żyjących w biedzie.

Jak zatem przedstawia się problem biedy i ludzi żyjących w ubóstwie na Białorusi w dyskursie akademickim oraz prasowym?

\section{PRZEMIANY HISTORYCZNE A UWZGLĘDNIANIE PROBLEMU UBÓSTWA I DEFINIOWANIE CZŁOWIEKA BIEDNEGO: OD OSÓB POTRZEBUJĄCYCH DO NAJBARDZIEJ POTRZEBUJĄCYCH}

Bieda na Białorusi nie pojawiła się nagle. Istniała zawsze, choć dotknięte nią były różne kategorie społeczne w zależności od warunków społeczno-politycznych i gospodarczych kraju. Od roku 1928 do czerwca 1941 trwała przyśpieszona industrializacja i ustalenie systemu kontroli prawie wszystkich sfer życia publicznego. Poziom życia ludności był wówczas skrajnie niski. Chłopi stanowili większość w strukturze społecznej. Cierpieli z powodu przymusowych przesiedleń i braku ziemi. Co więcej, w latach trzydziestych rozpoczął się proces kolektywizacji wsi, mający na celu likwidację kułactwa, uspołecznienie własności i stworzenie kołchozów. Z perspektywy dnia dzisiejszego można powiedzieć, iż kolektywizacja okazała się mechanizmem zubożenia białoruskiej wsi. Dowodzą tego niskie płace, a w większości kołchozów brak jakichkolwiek płac, brak urlopów, zwolnień lekarskich, urlopów macierzyńskich, w istocie brak emerytur oraz niemożność dysponowania paszportem.

Jeszcze w latach dwudziestych, jak wskazuje białoruski socjolog Sergej Shavel (1998), socjologowie, ekonomiści i kulturoznawcy prowadzili na Białorusi badania nad bieda, jednak od połowy lat trzydziestych do lat pięćdziesiątych socjologia w tym kraju (podobnie jak w innych krajach byłego Związku Radzieckiego) w zasadzie przestała istnieć, był to bowiem czas ekspansji światopoglądu totalitarnego, represji wobec naukowców i inteligencji. Bieda była tematem zabronionym, danych statystycznych dotyczących ludzi biednych nie zbierano.

Problem biedy w pewnym stopniu zaistniał publicznie w latach siedemdziesiątych, gdy został wprowadzony zasiłek dla rodzin żyjących w niedostatku. Od tej pory problem ubóstwa zawsze jest zagadnieniem polityki społecznej. W 1975 r. zostało ustanowione dochodowe kryterium biedy: dochód poniżej 80 rubli (około 70\$) miesięcznie na rodzinę. Oficjalne uznanie biedy za ważny problem społeczny nastąpiło w okresie transformacji i reform (lata osiemdziesiąte-dziewięćdziesiąte). Okres ten charakteryzuje rozpad więzi gospodarczych między byłymi republikami ZSRR, spadek tempa rozwoju gospodarki, spadek zatrudnienia i pojawienie się bezrobocia, znaczne obniżenie dochodów i poziomu życia ludności.

Przyjmując za granicę ubóstwa minimalny budżet spożycia, szacuje się, że stopa ubóstwa na Białorusi zwiększyła się z 5\% w 1990 r. do 53\% 
w 1994 r. Ryzyko niskich zarobków wzrosło wśród mieszkańców wsi, kobiet, kołchoźników, emerytów, osób samotnych mających kogoś na utrzymaniu. Najwyższą stopę ubóstwa zanotowano w grupie dzieci i młodzieży (do 16 lat). Był to wskaźnik rzędu 80\%, gdy dla całej populacji wynosił on $70 \%$, a dla emerytów (nie pracujących) około 54\% (zob. Golinowska 1996, s. 201).

Rozpad Związku Radzieckiego pociągnął za sobą pojawienie się problemu bezrobocia. W dramatycznej sytuacji znalazły się osoby zwalniane na skutek restrukturyzacji przedsiębiorstw, mieszkańcy monomiasteczek (takich, w których jedna fabryka zatrudniała prawie całą miejscową ludność). Warto zaznaczyć, że oficjalne bezrobocie na Białorusi od początku lat transformacji po dzień dzisiejszy oscyluje wokół 3\%. Problemem jest bezrobocie ukryte i nieoficjalne. Nadmiar zatrudnienia, wymuszone urlopy pracowników, niskie płace w sektorze państwowym stanowią realne uwarunkowania ubóstwa, a zatem począwszy od lat dziewięćdziesiątych bieda to przede wszystkim bieda pracujących, tak zwana nowa bieda. Do tej grupy nowych biednych Shavel, Rubanov i Smirnova (1998) zaliczają wykwalifikowanych pracowników sfery budżetowej: naukowców, profesorów, nauczycieli, lekarzy, pracowników w sferze kultury, wiejską inteligencję, robotników i urzędników gorzej usytuowanych przedsiębiorstw państwowych. Oto trafna charakterystyka tej grupy: „...bieda stała się zjawiskiem typowym nie tylko dla ludzi w ekstremalnych warunkach (bezrobotni, samotni rodzice i rodziny wielodzietne, niezdolni do pracy emeryci), lecz poniżej linii ubóstwa znaleźli się niestety także aktywni społecznie obywatele, ci, którzy żyli uczciwie, zarabiali na utrzymanie rodziny - pracownicy niektórych przedsiębiorstw zbrojeniowych, instytucji budżetowych (zwłaszcza kultury i sfery socjalnej), przedsiębiorstw rolniczych, którzy z powodu niskich zarobków nie mają możliwości zapewnienia, nawet według istniejących norm, utrzymania sobie i dzieciom (to «nowi biedni»)" (Lozhkina 1999, s. 40).

Powszechną strategią przetrwania w sytuacji zbyt niskich dochodów i opóźnienia wypłat była (i pozostaje) uprawa na działce owoców i warzyw (w tym obowiązkowo ziemniaków, nazywanych na Białorusi drugim chlebem), zbieranie jagód, grzybów w lasach, robienie przetworów na zimę. Wzrost produkcji rolnej w celu zaspokojenia potrzeb własnego gospodarstwa domowego (czasami również na sprzedaż) jest ważnym źródłem środków utrzymania dla $86 \%$ mieszkańców wsi i 34\% mieszkańców miast (dane za rok 2004; zob. Novosyolova 2004, s. 23). Wśród innych strategii na porządku dziennym znalazło się oszczędzanie, zapożyczanie się, redukcja potrzeb i inne. Niezwykle ważny jest kapitał społeczny, czyli utrzymanie dobrych relacji i wzajemnego wsparcia wśród członków rodziny, bliskich, znajomych.

Moment krytyczny to rok 1999, gdy liczba biednych oficjalnie wzrosła do 46\%. Spowodowano to było kryzysem finansowym 1998 r. w Rosji, ponieważ gospodarka Białorusi jest zależna od stanu rosyjskiej gospo- 
darki z powodu braku zasobów naturalnych, takich jak ropa naftowa czy gaz ziemny. Według białoruskich badaczy (Antonova 1999), pojawił się tzw. syndrom biedy, obejmujący grupy ludzi przyzwyczajonych do życia w nędzy i nie chcących zmienić swojej sytuacji. W polskiej socjologii pojęcie syndromu biedy jest zgoła odmienne. Oznacza kumulację czynników ubóstwa oraz dziedziczenie niskiego statusu społecznego w niektórych typach rodzin (Jarosz 2002).

Zmianę $\mathrm{w}$ podejściu do problematyki ubóstwa przyniósł oficjalny projekt przygotowany $\mathrm{w}$ roku 2001, poświęcony tzw. adresowanej pomocy potrzebującym (szerzej zob. Kanash 2007, s. 37-38). Idea polegała na tym, żeby zredukować liczbę osób potrzebujących, które znacząco obciążały wydatki na pomoc społeczną, przez reinterpretację kryterium biedy. W efekcie do grupy kwalifikujących się do adresowanej pomocy społecznej zaliczono osoby najbardziej potrzebujące, między innymi członków rodzin wielodzietnych, niepełnych, takich, w skład których wchodzi osoba niepełnosprawna. Wypadła $z$ kategorii potrzebujących rodzina składająca się $z$ dwóch rodziców pracujących za bardzo niską pensję i wychowujących dwójkę dzieci.

W 2003 r. przy współpracy Organizacji Narodów Zjednoczonych i rządu Republiki Białorusi podjęto realizację trzyletniego projektu zatytułowanego „Pomoc w przygotowaniu podstawowych kierunków narodowej strategii zapobiegania niedostatkowi i biedzie na Białorusi". Udział w projekcie wzięli Ministerstwo Pracy i Polityki Społecznej Republiki Białorusi, Ministerstwo Statystyki i Analiz oraz Bank Światowy. Zamierzano przeanalizować problemy związane $z$ biedą na Białorusi; poznać doświadczenia sąsiednich państw i zaadaptować te najbardziej udane; wypracować rekomendacje co do podstawowych kierunków przeciwdziałania biedzie; umocnić dialog i współpracę różnych organizacji zajmujących się tą problematyką. Innymi słowy, zadania projektu zakładały przeciwdziałanie skutkom biedy, a nie tylko jej zapobieganie ${ }^{1}$.

Mimo tak szerokich i interesujących założeń nie uniknięto pewnego kanonu przedstawienia problemów społecznych na Białorusi. Na przykład w liczącym 84 strony raporcie zatytułowanym „Podniesienie poziomu życia jako priorytet polityki społecznej. Przegląd zagranicznych doświadczeń” (2005) na temat Białorusi znajdujemy dwa akapity we wnioskach. W pierwszym czytamy: „Republika Białoruś wzięła kurs na społecznie zorientowaną gospodarkę i jednym z priorytetów polityki społecznej kraju jest udoskonalenie mechanizmu regulowania poziomu życia i dochodów ludności, systemu osłony socjalnej żyją-

${ }^{1} \mathrm{~W}$ wyniku projektu powstało kilka publikacji, w tym m.in. Socialnoje położenije $i$ urowien' żyzni nasielenija Riespubliki Biełarus' (2005), Socialno-trudowaja sfiera Riespubliki Biełarus' (2005), Powyszenije urownia żyzni kak prioritiet socjalnoj politiki. Obzor zarubieżnogo opyta (2005). Wszystkie są dostępne online: http://un.by/ru/undp/db/00011744.html 
cych w ubóstwie [matoobespieczennych] obywateli. Podejmowane przez państwo działania są skuteczne. Zgodnie $z$ danymi statystyk narodowych udział ludności o dochodzie poniżej budżetu minimum spożycia zmniejszył się z 38,4\% w 1995 r. do 17,8\% w 2004 r. Jednak problem biedy [małoobespieczennosti] wciąż pozostaje na Białorusi aktualny" 2 .

W tym samym raporcie zwraca uwagę pozytywna ocena sowieckiego dziedzictwa ${ }^{3}$. Wśród dodatnich stron tego dziedzictwa $\mathrm{w}$ krajach przechodzących transformację - w porównaniu z krajami rozwijającymi się - wymieniono mieszkania, ziemię i działki, usługi socjalne oferowane przez miejsca pracy (mieszkanie, opieka nad dzieckiem, edukacja), poziom edukacji, stan zdrowia, zabezpieczenia dla emerytów. Jednak pozytywne dziedzictwo socjalizmu - jak zauważają autorzy raportu — zaczyna topnieć pod wpływem tzw. czynników tradycyjnych, wśród których wymienia się wielodzietność, rodziny patologiczne, z których uciekają dzieci, zasilając szeregi bezdomnych (zwłaszcza w Rosji, gdzie jest około miliona bezdomnych dzieci). Zapomina się jednocześnie wspomnieć o negatywnych aspektach dziedzictwa gospodarki socjalistycznej (np. wyuczona bezradność, zrównanie poziomu życia różnych warstw społecznych, gospodarka centralnie planowana nie pozwalająca na rozwój prywatnego biznesu, inicjatywy). Jak trafnie napisała białoruska badaczka Natalia Prokofyeva (2003, s. 1): „Białoruś przejęła dziedzictwo Związku Radzieckiego. Jest ostatnim państwem typu sowieckiego, rodzajem mini-ZSRR. Parkiem jurajskim, w którym są wszystkie aspekty życia codziennego tego państwa, z ukrytą sowiecką nędzą włącznie".

$\mathrm{W}$ podsumowaniu należy zwrócić uwagę na następujące cechy białoruskiego dyskursu akademickiego: w ciągu ostatnich dziesięciu lat wzrosło zainteresowanie problematyką ubóstwa; w białoruskiej socjologii temat biedy sytuuje się $\mathrm{w}$ ramach analiz poziomu jakości życia oraz polityki społecznej, a nie jako odrębne zagadnienie (tymczasem na przykład w Polsce znajdujemy studia poświęcone wyłącznie zagadnieniu biedy; np. zbiór Polska bieda pod redakcją Stanisławy Golinowskiej); systematyczne i kompleksowe badania nad ubóstwem są przeprowadzane przez ONZ oraz Bank Światowy w ścisłej współpracy $z$ rządem. Bieda jest definiowana przez odwołanie do niskich dochodów, społeczny wymiar biedy pojawia się $\mathrm{w}$ badaniach organizacji międzynarodowych. Bieda jest traktowana $\mathrm{w}$ różnych badaniach jako zjawisko zarówno statyczne, jak i dynamiczne, absolutne lub relatywne, dominują wskazania na jej przyczyny ekonomiczne.

2 ONZ, Projekt nacionalnoj strategii priedotwraszczenija biednosti w Respublikie Bietarus'. 2003-2006. Powyszenije urownia żizni kak prioritiet socjalnoj politiki. Obzor zarubieżnogo opyta, 2005, s. 75 (http://un.by/ru/undp/db/00011744.html).

3 Tamże, s. 14-15. 


\section{O KRYTERIACH UBÓSTWA: KOGO UZNAJE SIĘ ZA BIEDNEGO I KTO SIEBIE UWAŻA ZA OSOBĘ BIEDNĄ?}

Podczas rozpatrywania zjawiska biedy na Białorusi należy brać pod uwagę ustawy: „O tworzeniu i wykorzystaniu minimalnego budżetu spożycia” (1992) oraz „O minimum spożycia na Białorusi” (styczeń 1999). Oficjalnie na Białorusi nie używa się w zasadzie terminu „linia ubóstwa”, bieda. Zamiast tego funkcjonuje pojęcie „rodziny żyjące w niedostatku” (które według obiektywnych przyczyn mają średni dochód poniżej budżetu minimum spożycia - BMS).

W analizach warunków i poziomu życia ludności są wykorzystywane orientacyjne linie ubóstwa: do $1994 \mathrm{r}$. było to $50 \%$ minimalnego budżetu spożycia (MBS), do 1999 r. 60\% MBS, a od 1999 r. 100\% BMS. Minimum spożycia (MS) to zaspokojenie minimalnych potrzeb fizjologicznych, budżet minimum spożycia to minimalne spożycie podstawowych produktów i usług wyrażone w cenach plus podatki, minimalny budżet spożycia to suma minimalnych potrzeb fizjologicznych i społeczno-kulturowych ${ }^{4}$. MS, BMS, MBS są obliczane dla podstawowych grup społeczno-demograficznych (ludzie $\mathrm{w}$ wieku produkcyjnym, emeryci, dzieci). Na przykład BMS w grudniu 2009 r. wynosił około 255,2 tys. rubli białoruskich (80 USD lub około 255,2 PLN). Budżet minimum spożycia na Białorusi obejmuje (według cen z czerwca 2010 r.) wydatki średnio na jedną osobę na wyżywienie $(54,2 \%)$, mieszkanie $(16,1 \%)$, odzież i obuwie $(17,0 \%)$, usługi (fryzjer, naprawa butów i naprawa towarów trwałego użytku) i transport $(6,7 \%)$, sprzęt domowy i AGD $(3,3 \%)$, wpłaty i opłaty (np. na komitet rodzicielski w szkole czy na przedszkole, podatek dochodowy i wpłata na fundusz socjalny dla osób pracujących $-0,4 \%$ ), najbardziej podstawowe przedmioty higieny osobistej i leki $(2,2 \%)$. Minimum spożycia na Białorusi to kategoria różniąca się zarówno od minimum egzystencji, jak i od minimum socjalnego w Polsce. Inaczej niż polskie minimum egzystencji obejmuje ponadto transport (jeden bilet 30-dniowy na jeden rodzaj transportu lokalnego), sprzęt domowy, wpłaty i opłaty, a w odróżnieniu od polskiego minimum socjalnego nie uwzględnia wydatków na kulturę (oprócz posiadania telewizora), sport i wypoczynek, łączność. W białoruskich szkołach podręczniki wydawane są przez biblioteki nieodpłatnie na czas roku szkolnego, stąd brak odpowiedniej pozycji w minimum spożycia.

Udział w społeczeństwie ludności żyjącej poniżej MBS w 1995 r. wynosił, zgodnie z danymi Ministerstwa Statystyki i Analiz Republiki Białorusi, 80,4\%,

4 Używam tu pojęcia „minimum spożycia” jako odpowiednika terminu prożitocznyj minimum. Dosłownie jest to „minimum przeżycia” (tak jest odbierany i jako taki jest krytykowany przez niespecjalistów na łamach prasy białoruskiej), w słownikach rosyjsko-polskich jest tłumaczony jako „minimum egzystencji”, „minimum socjalne”, co dla polskiego czytelnika może być mylące. O różnicach między minimum egzystencji w Polsce a minimum socjalnym w krajach byłego Związku Radzieckiego pisała Stanisława Golinowska (1996, s. 9). 
w 2000 r. 76,8\%; poniżej minimum spożycia w 1995 r. znajdowało się 39,9\%, w 2000 r. 41,9\% (ostatnie dwie liczby to udział w społeczeństwie tych, którzy są uważani za potrzebujących pomocy społecznej). Poniżej budżetu minimum spożycia według danych za IV kwartał 2009 r. znajdowało się 5,4\% ludności kraju. Jest to tzw. bieda absolutna. Ponadto ekonomiści z niezależnego Centrum Badawczego Instytutu Przedsiębiorczości i Zarządzania Aleksandr Chubrik i Gleb Shymanovich (2010) zwracają uwagę na osoby znajdujące się nieco powyżej linii ubóstwa. Takich potencjalnie absolutnie biednych jest około 6\%.

Oficjalna przyjęta przez państwo definicja ubóstwa tak naprawdę równa się kwestii identyfikacji podmiotu polityki społecznej. Łatwo przy tym o nieporozumienia i zafałszowanie obrazu. „Tradycyjne posługiwanie się jako miernikiem stopą ubóstwa [liczba ludności żyjącej poniżej linii ubóstwa w stosunku do całej populacji - T.K.] może w ramach takich zasobów informacji wypaczać politykę zwalczania ubóstwa, ponieważ nie uwzględnia gorszej sytuacji tych, którzy są biedniejsi wśród biednych. Każdy rząd mając taki miernik jak stopa ubóstwa będzie miał wyraźną skłonność do koncentrowania się na bardziej zamożnych biednych, ponieważ może w ten sposób najłatwiej zmniejszyć ich liczbę, a więc i stopę ubóstwa [...]" (Sen 2000, s. 128). Najogólniej można powiedzieć, że oficjalne (normatywne) linie biedy to ustalenia odgórne, polityczno-ideologiczne, nie odzwierciedlają one istoty analizowanego zjawiska, nie pozwalają zobaczyć całościowego obrazu biedy.

W dyskursie naukowo-badawczym bieda jest przedstawiana nie tylko normatywnie, lecz również statystycznie. Obiektem takich badań są przede wszystkim gospodarstwa domowe. Na Białorusi prowadzone są one od 1995 r. na reprezentatywnej ogólnokrajowej próbie, obejmującej 6 tys. rodzin. Badania te stanowią ważne źródło informacji, chociaż mają pewne ograniczenia. Mówi się o tym, że: respondenci zaniżają dochody i pomoc, jaką otrzymują od bliskich; zatarciu ulegają takie aspekty, jak mobilność biedy, jej sezonowość, czas trwania - czynniki te są ważne podczas formułowania strategii przeciwdziałania. Metoda ilościowa jest jednak bardzo ważna i cenna, ponieważ pozwala na uczulenie polityków na wielkość grup społecznych rzeczywiście dotkniętych ubóstwem i w praktyce jest jedynym źródłem danych pozwalających je wyznaczyć; dostarcza reprezentatywnych wyników oraz pozwala na ich porównanie w różnych latach.

Do kategorii biednych na Białorusi można byłoby zaliczyć mieszkańców wsi, kobiety, osoby o niskich dochodach w wieku 25-54 lat (czyli ludność $\mathrm{w}$ wieku produkcyjnym) i dzieci w wieku 0-15 lat. Zgodnie $z$ danymi, najbiedniejsze są rodziny wielodzietne (mające na utrzymaniu troje i więcej dzieci) i rodziny, w których są bezrobotni, zarówno w mieście, jak i na wsi. Bieda dotyka zwłaszcza te gospodarstwa domowe, w których głowa rodziny ma wykształcenie średnie, podstawowe, jest robotnikiem lub emerytem. Analizując terytorialne rozmieszczenie biednych gospodarstw domowych, można wskazać na obwody mohylewski, homelski, witebski, brzeski jako bardziej zagrożone 
ubóstwem, w lepszej sytuacji znajduje się Mińsk i obwód miński, obwód grodnieński. Specjaliści podkreślają, że największe dysproporcje rysują się wokół podziału według miejsca zamieszkania: miasto lub wieś. Najbiedniejsze są tereny wiejskie, zwłaszcza w obwodzie mohylewskim i homelskim. Szacuje się, że w tych regionach 5,8\% i 4,8\% ludności uzyskuje dochód dwa razy niższy od ustalonego budżetu minimum spożycia ${ }^{5}$. Kryzys rolnictwa w latach 1991-2003 spowodował znaczne opóźnienia w wypłatach i tak niskich wynagrodzeń.

Socjologowie dostrzegają złożoność problemu ubóstwa. Na przykład Sergej Shavel wyróżnia trzy typy biedy: „niewielka” (niebolshaja), kiedy udaje się wiązać koniec z końcem, „zauważalna” (zamietnaja) oznacza znaczną redukcję potrzeb i poszukiwanie najtańszych produktów spożywczych, brak możliwości zaspokojenia potrzeb kulturowych, i „katastroficzna” (katastroficzieskaja), która powstaje wtedy, gdy brakuje stałego dochodu, źródłem utrzymania są zasiłki z pomocy społecznej, a ponieważ z zasiłku nie da się utrzymać, biedni podejmują dowolną pracę (zob. Serzhan 2004). W tym kontekście Ludmiła Istomina (2002) zwraca uwagę na różnicę między biedą krótkotrwałą i długotrwałą.

Spójrzmy teraz na obraz biedy wyłaniający się z sondaży. Zastanówmy się, czy ludzie są zadowoleni z życia? Badania subiektywnej oceny sytuacji materialnej różnych grup społecznych znajdują się w centrum uwagi dyskursu akademickiego od początku lat dziewięćdziesiątych. Są one swojego rodzaju barometrem zmian gospodarczych, świadczą o załamaniu, polepszeniu lub stabilizacji gospodarki, a także o mobilności biedy. W sondażach ponad połowa mieszkańców Białorusi uznaje problemy społeczno-ekonomiczne (w tym biedę i bezrobocie) za najważniejsze, na dalszy plan odsuwając problemy polityczne, przestrzegania praw człowieka oraz ekologiczne (Titarenko 2005, s. 2).

$\mathrm{Z}$ kolei badanie białoruskich gospodarstw domowych prowadzone przez Ministerstwo Statystyki i Analiz na reprezentatywnej próbie 5005 gospodarstw domowych pokazało, że w latach 1999-2000 więcej niż połowa gospodarstw domowych była niezadowolona ze swojej sytuacji materialnej. Generalnie w 2000 r. sytuacja polepszyła się, procent niezadowolonych zmalał. Najbardziej niezadowoleni to mieszkańcy stolicy (przy czym mają oni najwyższe aspiracje i wymagania dotyczące jakości życia, a także większe możliwości wyrażania swojego niezadowolenia), podczas gdy zadowolenie na wsi wzrosło. Liczba zadowolonych kształtuje się w przedziale $3-5 \%$, podczas gdy niezadowolonych jest $60-70 \%$. Dane wskazują, że ludzie oceniają swoją sytuację gorzej niż można by sądzić na podstawie statystyk. Mimo niezadowolenia podejmują różne strategie zaradcze, adaptacyjne.

Bieda i bezrobocie bardziej dotykają kobiety niż mężczyzn (chociaż sytuacja przeżywania ubóstwa przez biednych mężczyzn pozostaje otwartym polem badawczym). To kobiety mają niższą pozycję na białoruskim rynku pracy

5 ONZ, Ekonomika i obszczestwo Biełarusi: disproporcii i pierspiektiwy razwitija. 2004-2005, s. 39-40 (http://un.by/pdf/1321_rus_.pdf). 
(praca $\mathrm{w}$ sektorach edukacji, ochrony zdrowia, kultury i in.) i niższe zarobki (3/4 zarobków mężczyzn zgodnie $z$ danymi Banku Światowego) oraz ograniczony udział w kierowaniu i podejmowaniu decyzji.

Zjawisko feminizacji biedy stało się powszechne na Białorusi w latach dziewięćdziesiątych, ciężar procesów transformacji miał wówczas silny wpływ na sytuację społeczno-ekonomiczną kobiet. W dyskursie naukowo-badawczym bieda kobiet została zdefiniowana najpierw w badaniach Banku Światowego w 1994 r., później w latach 2000-2001 temat podjęła Aleksandra Aleksandrova w badaniu pt. „Skala biedy kobiet na Białorusi”. Pierwszy etap stanowił ogólnokrajowy kwestionariuszowy sondaż pt. „Skala biedy kobiet w Republice Białorusi”, etap drugi - jakościowe badanie pt. „Postrzeganie biedy przez białoruskie kobiety i ich strategie zaradcze”. W sondażu wzięło udział 778 kobiet (badania reprezentatywne, błąd próby 3\%). Wyniki wskazują, że $74 \%$ kobiet należy do kategorii biednych, to znaczy mają dochód poniżej 2 \$ dziennie (taka sama liczba kobiet wydaje na produkty żywnościowe do $50 \%$ swoich dochodów), 64\% kobiet uważa siebie za biedne.

Jako przyczyny ubóstwa w badaniach Aleksandrovej kobiety wskazywały: niskie płace (uważało tak $87,5 \%$ badanych), pogorszenie stanu zdrowia i złą sytuację ekologiczną $(36,7 \%)$, niewystarczającą pomoc państwa $(35,9 \%)$, niesprawiedliwy system dystrybucji dochodów $(34,4 \%)$, opóźnienia wypłat pensji $(30,7 \%)$, rozpad rodziny, rozwód $(26,4 \%)$, wychowanie dzieci w niepełnych rodzinach $(26,3 \%)$, utratę pracy $(28,7 \%)$, brak odpowiedniego poziomu edukacji $(33,4 \%)$, brak odpowiednich umiejętności zawodowych (29,6\%). Jak widać, wymieniane przyczyny ubóstwa są różne: dotyczą czynników makrostrukturalnych i mikrospołecznych (rodziny). Dominują wyraźnie czynniki zewnętrzne.

Interesujące wyniki badań odnoszą się do sposobów przezwyciężania biedy. Ustalono, iż $82,1 \%$ kobiet uważa, że to państwo powinno pomagać, gwarantując odpowiedni poziom dochodu, ale $81 \%$ respondentek w trudnej sytuacji materialnej liczy tylko na własne siły. Kobiety nie oczekują w praktyce żadnej pomocy od organizacji pozarządowych oraz związków zawodowych (tylko 0,6\% o tym wspomina). Może to świadczyć o niskim poziomie rozwoju społeczeństwa obywatelskiego. $72,4 \%$ kobiet uważa, że polepszyć sytuację ekonomiczną w kraju mogą reformy rynkowe.

W 2003 r. podczas międzynarodowej konferencji „Kobieta. Edukacja. Demokracja", zorganizowanej przez niepaństwowy Instytut Kobiet ENWILA, zostały zaprezentowane dwa referaty na temat biedy kobiet. Autorka jednego z nich (Osipova 2003, s. 94) zwróciła wówczas uwagę na tendencję do feminizacji ubóstwa na Białorusi. Dostrzegła ponadto tzw. wtórne ubóstwo kobiet, polegające na tym, że zamiast zaspokoić własne niezbędne potrzeby (na przykład przez zakup kosztownych leków) kobieta angażuje się w zaspokojenie niezbędnych potrzeb innych członków rodziny. W innym referacie (Rapiecka 2003) znajdujemy rozważania na temat „biednych pracujących” kobiet. 
Bieda dzieci jest ukryta w badaniach dotyczących biedy kobiet, w statystykach i badaniach wielodzietnych gospodarstw domowych. Zagadnienie to wymaga dodatkowych badań. Szczątkowych informacji dostarcza raport autorów zagranicznych Daniela Wordswortha, Marka McPeaka, Thomasa Feeny'ego pt. Understanding Children's Experience of Poverty (2005), w którym do przedstawienia biedy dzieci wykorzystane są takie pojęcia, jak exclusion, deprivation, vulnerability. Wśród głosów dzieci z Indii, Kenii, Boliwii, Sierra Leone znajdujemy tam również opinie dzieci z Białorusi. Dzieci silnie odczuwają swój niższy status społeczny, są napiętnowane przez lepiej sytuowanych rówieśników. Oto zawarty $w$ raporcie cytat $z$ wypowiedzi siedemnastoletniej dziewczyny z Mińska: „Bieda oznacza nierówne stosunki z innymi. Jeśli jesteś biedny, to jesteś naznaczony. Inni patrzą na ciebie w pewien szczególny sposób, jakbyś był bezwartościowy. Czuję się jak ktoś nieważny: nikt nie chce mnie słuchać, nikt się o mnie nie troszczy... Jestem biedna, nie liczę się..." (Wordsworth, McPeak, Feeny 2005, s. 16). W raporcie tym brakuje głębszej i systematycznej analizy sytuacji dzieci na Białorusi. W opracowaniach tego rodzaju łatwiej bowiem uchwycić podobieństwa niż specyfikę sytuacji w poszczególnych krajach.

\section{DYSKURS PRASOWY, CZYLI BIEDA JAKO KONSTRUKCJA SPOŁECZNO-POLITYCZNA}

Prasa jak większość środków masowego przekazu jest zdominowana przez białoruskie państwo. Istnieją jednak nieliczne tytuły gazet prezentujące opinie krytyczne, niezgodne z polityką rządzących. Największy nakład ma dziennik rządowy „Sowietskaja Biełarus' - Biełarus' Siegodnia” [„SB”] (ok. 500 tys.), a wśród prasy niezależnej gazeta „Narodnaja Wola” [„NW”] (ok. 41 tys.) i tygodnik „Biełorusskij Rynok - Biełarusy i Rynek” [„BR”] (13 tys.). Artykuły na temat ubóstwa na Białorusi pochodzące $z$ tych trzech gazet $z$ okresu od 1 stycznia 1996 r. do 9 kwietnia 2005 r. zostały poddane analizie. Początek tego okresu to pierwszy rok funkcjonowania niepaństwowej gazety „Narodnaja Wola”, w roku 2005 zaś przeprowadzono badania, metodą jakościowej analizy treści. Poszczególne artykuły zostały dobrane za pośrednictwem strony internetowej archiwum medialnego Białorusi (http://bymedia.net). Początkowo wykorzystano następujące słowa kluczowe: bieda, biedny, biedni, żyć w biedzie, w nędzy, prowadzić życie $\mathrm{w}$ nędzy, osoby żyjące $\mathrm{w}$ niedostatku, ubogie, potrzebujące, marginalizacja, marginalność, człowiek zmarginalizowany, wykluczenie, minimum spożycia, pomoc biednym, pomoc adresowana do najbardziej potrzebujących, dobroczynność, bezdomność, bezdomny, żebracy, żebrać, deprywacja, podklasa. Drugi etap selekcji wyłonił artykuły, w których bieda dotyczyła jednostek i grup społecznych, a nie stanu gospodarki. Odrzucone zostały również teksty mówiące o biedzie w innych krajach, gdyż nosiły one charakter krótkich informacji bez odniesienia do sytuacji na Białorusi. 
Ostatecznie próba (celowa, niereprezentatywna) zawierała 82 artykuły „BR”, 43 artykuły „NW” oraz 128 artykułów „SB”. Jednostkami analizy były wypowiedzi albo artykuły, które zawierały jedną ideę lub temat. Zastosowana technika analizy danych to porównanie (między trzema gazetami według głównych tematów oraz kategorii analizy). Wyniki zostały opisane oraz przedstawione przez przytoczenie wypowiedzi czytelników lub innych aktorów dyskursu prasowego. Tutaj ograniczę się do wniosków ogólniejszych.

W analizowanym materiale zostały dostrzeżone różne reguły prowadzenia dyskursu. Gazety niezależne korzystają ze strategii wyolbrzymiania problemu ubóstwa i porównują biedę na Białorusi z sytuacją w Stanach Zjednoczonych i Europie Zachodniej. Z kolei gazeta państwowa pomniejsza problem - porównuje ubóstwo na Białorusi z jego przejawami w najuboższych krajach świata. Na łamach gazet możemy dostrzec również strategię zrównoważoną - dokonywane są wtedy porównania $z$ krajami regionu (były Związek Radziecki).

Udział osób biednych wpływa na obraz struktury społecznej. W gazecie rządowej takich osób jest znacznie mniej niż przedstawicieli klasy średniej, $\mathrm{w}$ prasie niepaństwowej zaś czytamy o ich większej liczbie i braku w zasadzie klasy średniej. Kolejna kwestia dotyczy nierówności społecznych, które są wyolbrzymione w prasie niepaństwowej, a pomniejszone w rządowej.

Badania pokazują, że bieda i biedni w rządowej „SB” są przywoływani za pomocą kategorii „potrzebujący” (małoobiespieczennyje, nużdajuszczijesia), w niezależnej „NW” oraz analitycznej „BR” zaś najczęściej występują określenia „nędza” oraz „skrajne ubóstwo”. Bieda w prasie państwowej jest traktowana w kategoriach możliwości i powinności (co jest możliwe do realizacji w obszarze polityki społecznej i co niezbędne), w prasie niepaństwowej — w kategoriach realnych (jak jest) i idealnych (co nie zawsze możliwe do realizacji). W państwowej prasie bieda jest ujmowana przez wskazanie na ilość brakujących produktów i usług, a w niepaństwowej bierze się pod uwagę ponadto ich jakość.

W przeanalizowanych materiałach „SB” przyczyn biedy upatruje się w braku osobistej odpowiedzialności. Odpowiedzialni za nią są także urzędnicy i władze lokalne. W analizowanej prasie niepaństwowej odpowiedzialność spoczywa na rządzie i politykach. Według niezależnej „NW” przyczyny biedy są zróżnicowane (ekonomiczne, polityczne, kulturowe oraz indywidualne). Analityczna „BR” zwraca uwagę na ekonomiczne źródła ubóstwa. W rządowej „SB” zaś na pierwszym planie pojawiają się moralne czynniki ubóstwa. Przedstawiane są tam również psychologiczne aspekty biedy, podczas gdy w „NW” dominują jej konsekwencje polityczne oraz ekonomiczne.

Biedni na stronach rządowej „SB” to najczęściej bezdomni, żebracy, rodziny wielodzietne, dzieci. Analityczna „BR” pokazuje głównie obrazy „biednych pracujących”, a niezależna „NW" pisze o nisko i wysoko wykwalifikowanych pracownikach upadających przedsiębiorstw, pracownikach sfery usług, pracują- 
cych w niepełnym wymiarze godzin oraz o rodzinach bezrobotnych. Czytelnicy mają ambiwalentny stosunek do osób ubogich: zarówno im współczują, jak i wyrażają ubolewanie. Dowodem na to są ich wypowiedzi na temat osób bezdomnych.

Prezydencka „SB” wyraża opinię, że walka z biedą jest realna i że istnieją różne sposoby jej zwalczania, $\mathrm{w}$ tym urzędowe regulacje oraz starania ze strony państwa. Stanowisko dwóch innych gazet jest odmienne, zawiera głęboki pesymizm w tej kwestii. Rządowa „SB” przedstawia czytelnikom zarówno pozytywne, jak i negatywne oceny działań państwa oraz organizacji dobroczynnych działających na rzecz ubogich. „BR” oraz „NW” natomiast ogólnie krytycznie patrzą na działania rządu w walce $z$ biedą.

W nawiązaniu do teoretycznych koncepcji biedy rządowa „SB” rysuje obrazy zmarginalizowanych osób i grup społecznych, podczas gdy niepaństwowa „NW" skupia uwagę na wykluczonych. Analityczno-ekonomiczna „BR” przedstawia głównie trendy ubóstwa, a nie osobiste doświadczenia ludzi żyjących w biedzie.

Wbrew wstępnym hipotezom, gazeta rządowa poświęca najwięcej miejsca problemom ubóstwa, zwłaszcza tzw. biedzie tradycyjnej (przy takim celowym doborze próby). Gazeta niezależna najmniej opowiada o biedzie. Częstotliwość występowania kategorii „bieda” w analizowanych artykułach wynosi 131 dla „SB”, 44 dla „NW” oraz 76 dla „BR”, a kategorii „potrzebujący” odpowiednio 46 i 90 dla „SB”, 5 i 10 dla „NW” oraz 21 i 43 dla „BR”. Wytłumaczeniem tego faktu może być zarówno ograniczona objętość gazety „NW” (4 strony formatu A2) w porównaniu z „SB” (8 stron A2), jak i różnice w założeniach programowych (w centrum zainteresowania niepaństwowej „NW” jest godność, prawa i wolności każdego człowieka, a nie tylko biednego).

Wśród czytelników gazet wypowiadających się na temat ubóstwa, poziomu życia grupą szczególnie aktywną są emeryci i kobiety z dziećmi. To oni mają odwagę dzielić się własną historią z czytelnikami i dziennikarzami. W niektórych ich listach można odczuć rozpacz, rozgoryczenie. Brakuje w nich nadziei.

Które aspekty ubóstwa w analizowanym dyskursie prasowym zostały ukryte lub zajmują pozycję marginalną? Jest to bieda w kontekście historycznym, kulturowym, przemian społecznych, realizacji praw i uprawnień, migracji, struktury społecznej. W zebranym materiale brak głosu polityków o biedzie. Również siła głosu osób biednych jest w dyskursie prasowym niewielka. Jest to jeden $z$ aspektów zjawiska biedy, określany przez badaczy amerykańskich (Bullock, Wyche, Williams 2001) mianem niewidzialności (invisibility). Drugi aspekt niewidzialności polega na tym, że o biednych opowiadają bardziej zamożni członkowie społeczeństwa: eksperci, dziennikarze, czytelnicy. $\mathrm{Na}$ marginesie pozostają informacje o życiu codziennym osób biednych, ich strategiach radzenia $z$ ubóstwem, a przede wszystkim ich własne opinie i odczucia. 


\section{CO DAJE PORÓWNANIE DYSKURSU AKADEMICKIEGO I PRASOWEGO NA TEMAT BIEDY?}

Po pierwsze, zestawienie tych podejść umożliwia szersze spojrzenie na problematykę ubóstwa. Dyskurs akademicki dostarcza perspektywy badawczej, dyskurs prasowy pokazuje konflikt interesów różnych aktorów (czytelników i ekspertów, biednych i niebiednych).

Po drugie, różne dyskursy składają się na pełnię obrazu, przedstawiając różne aspekty analizowanego problemu. Dyskurs akademicki charakteryzuje dominacja podejścia makrospołecznego. Bieda jest definiowana za pomocą ustalonych wskaźników i przede wszystkim w odniesieniu do gospodarstw domowych. W dyskursie prasowym spotykamy portrety osób bezdomnych, w tym bezdomnych dzieci, osób samotnych, wreszcie osób uważających siebie za biedne i proszących o pomoc. Poznajemy też opinie ludzi mieszkających w różnych regionach kraju, o różnej pozycji społecznej, mężczyzn i kobiet.

Po trzecie, w mniej demokratycznych państwach prasa niepaństwowa oferuje badaczom możliwość bardziej odważnego wypowiadania się na drażliwe tematy społeczne, które raczej trudno poruszać w oficjalnym środowisku naukowym.

Te trzy stwierdzenia mają charakter ogólny. Warto pamiętać, że nie istnieje jednolity dyskurs akademicki i jednolity dyskurs prasowy. Każdy z nich ma cechy instytucji państwowych, niepaństwowych i międzynarodowych.

Analiza badanych dyskursów nie tylko mówi o biedzie i sytuacji osób biednych, lecz również coś więcej na temat samego społeczeństwa, mechanizmów jego funkcjonowania. Znakomity badacz przemian współczesnego świata Zygmunt Bauman $(1998$, s. 4) trafnie zauważył, iż „każde społeczeństwo tworzy swych biednych na kształt i podobieństwo swoje". Myśl tę można rozwinąć i dodać, iż różni aktorzy społeczni czynią to w różny sposób. Inaczej rysuje obrazy biedy prasa państwowa i niepaństwowa, inaczej też ludzie żyjący w ubóstwie są ukazywani przez naukowców (pracujących w sektorze państwowym i niepaństwowym), dziennikarzy i zwykłych obywateli.

Dyskurs akademicki rządzi się między innymi regułą przemilczania niewygodnych problemów biedy (na przykład w publikacjach poświęconych zagadnieniom ubóstwa nie są rozpatrywane $\mathrm{w}$ ogóle lub $\mathrm{w}$ dostatecznym stopniu problemy osób bezdomnych, żebraków, dzieci ulicy, związków biedy i bezrobocia). Z kolei dyskurs prasowy często wykorzystuje regułę selekcji przez dobór pojedynczych przypadków oraz wyolbrzymienie bądź pomniejszenie wagi problemu. Aksjologiczny dyskurs prasowy pokazuje negatywny obraz pobierających zasiłki, kładąc nacisk na osobistą odpowiedzialność biednych, czego nie ma w analizowanych materiałach dyskursu akademickiego.

Pojęcia „marginalizacja”, „deprywacja”, „wykluczenie społeczne” oraz „podklasa" nie są popularne w żadnym $z$ białoruskich dyskursów na temat biedy, co nie znaczy, że nie ma ich w szerszym kontekście. Analizując najświeższe publi- 
kacje (w tym pochodzące $z$ instytucji niepaństwowych), można wnioskować, że pojęcie „biedy” weszło już do leksykonu badaczy na Białorusi. Jednocześnie jako synonim używane jest pojęcie opisujące osoby żyjące w niedostatku [matoobespieczennost']. Posługiwanie się tym pojęciem z jednej strony może służyć ukrywaniu biedy, z drugiej jest mniej wartościujące, nie piętnuje osób biednych tak jak „ubogi”, „zmarginalizowany”, „wykluczony”.

W dyskursie akademickim profil biedy na Białorusi obejmuje rodziny wielodzietne, osoby z niskim wykształceniem, mieszkańców wsi, pracujących w sektorze państwowym oraz zamieszkujących obwody mohylewski i homelski. Ogólny profil biedy w dyskursie prasowym obejmuje bezdomnych, żebraków, rodziny wielodzietne, emerytów, mieszkańców wsi, osoby z niskim wykształceniem, samotne matki, osoby niepełnosprawne, dzieci, biednych pracujących, rodziny osób bezrobotnych oraz kobiety. Oba dyskursy pokazują, że często dochodzi do kumulacji czynników ubóstwa: na przykład biedni najczęściej mają zarówno niski poziom wykształcenia, jak i mieszkają w niekorzystnych warunkach.

\section{BIBLIOGRAFIA}

Aleksandrova Aleksandra, 2001, Massztaby biednosti żenszczin w Riespublike Biełarus': mnogokriterialnaja ocenka, „Ekonomiczeskaja sociologija”, t. 2, nr 4 (www.ecsoc.msses. $\mathrm{ru})$.

Aleksandrova Aleksandra, 2002, Massztaby biednosti sriedi żenszczin Riespubliki Biełarus', portal informacyjny Open Women Line (http://www.owl.ru ).

Aleksandrova Aleksandra, Massztaby żanoczaj biednasti u Biełarusi: wyniki sacyjalagicznaga das'ledawan'nja, „Czaławiek. Prawaabaronczy biuletien”, , nr 5 (9), s. 5-7.

Antonova Tatiana, 1999, Osnownyje naprawlenija socialnoj politiki Riespubliki Biełarus' w obtasti podderżki piensionerow, siemji, zaniatosti nasielenija, w: Socialnyje problemy Riespubliki Biełarus'. Sbornik naucznych trudow, ISPI pri Administracii Priezidienta Riespubliki Biełarus', Mińsk.

Avdej O. V., 1999, Granicy gosudarstwiennogo riegulirowanija w ekonomiczeskoj modeli czetowieka, „Trudy bel. gos.tehn. uniwiersitieta”, nr 5, Ekonomika i uprawlenie, Mińsk.

Bauman Zygmunt, 1998, Zbędni, niechciani, odtrąceni_czyli o biednych w zamożnym świecie, „Kultura i Społeczeństwo”, nr 2.

Bullock Heather E., Wyche Fraser Karen, Williams Wendy R., 2001, Media Images of the Poor, „Journal of Social Issues", t. 57, nr 2.

Cheshchevik Anton (red.), 2002, Socialnaja sfiera Riespubliki Biełarus'. Riegionalnyje aspiekty, ISPI, Minsk.

Chubrik Aleksandr, Shymanovich Gleb, 2010, Socialnyje posledstwija ekonomiczeskogo krizisa w Biełarusi i naprawlenija izmienienij socialnoj politiki, materiał roboczy Badawczego Centrum Instytutu Przedsiębiorczości i Zarządzania (http://research.by).

Galubovich V. I. (red.), 1999, Ekanamicznaja gistoryja Biełarusi, Ekaperspektywa, Mińsk. Golinowska Stanisława, 1996, Badania nad ubóstwem. Zatożenia $i$ metoda, w: Stanisława Golinowska (red.), Polska bieda, IPiSS, Warszawa.

Istomina Ludmiła, 2002, Puszczat' — nie puszczat’?, „Biełaruskij rynok”, 28 października. 
Jarosz Maria, 2002, Ubóstwo, w: Encyklopedia socjologii, t. 4, Oficyna Naukowa, Warszawa. Kanash Tatsiana, 2006, „Poverty Issues in Belarus: An Analysis of Academic and Media Discourses" (maszynopis pracy doktorskiej).

Kanash Tatsiana, 2007, Challenges for Welfare Policies In Belarus: Poor Families with Many Children, w: Toma Burean (red.), Faces of Post-communism: Central and Eastern Europe's Social, Political and Cultural Experiences, IFiS Publishers, Warsaw.

Kurowski Piotr, 2002, Koszyki minimum socjalnego i minimum egzystencji - dotychczasowe podejście, IPiSS, Warszawa (http://www.ipiss.com.pl/teksty/kurowski.pdf).

Lozhkina L. N., 1999, Socialnaja zaszczita matoobiespieczennych stojow nasielenija Riespubliki Biełarus' w ustowijach transformacii obszczestwa, w: Socialnyje problemy Riespubliki Biełarus'. Sbornik naucznych trudow, ISPI pri Administracii Priezidienta Respubliki Biełarus', Mińsk.

Mitskevich Janna, Turovets Andrei, 2003, Changes of the Social Policy Model in the Republic of Belarus in the Relation to the Needy, w: Maria Bocheńska-Seweryn, Jolanta Grotowska-Leder (red.), Old and New Poverty in Post-Communist Europe, IS UJ, Kraków.

Morova Antonina, 1999, Socialnaja zaszczita nasielenija i problemy biednosti $w$ Bietarusi, „Biełorusskij ekonomiczeskij żurnał”, nr 1.

Novosyolova S. V., 2004, Ocenka urownia żizni nasielenieja Riespubliki Biełarus', w: Materiały międzynarodowej konferencji „Dostiżenije pierwoj celi tysiaczeletija: konceptualnyje podhody i puti riealizacii”. ONZ i Rząd Republiki Białoruś, Mińsk (http://un.by).

Osipova G., 2003, Ekonomiczeskoe ranzirowanije po giendernomu priznaku, ili diejstwitielno li biednost' nie porok?, w: Żenszczina. Obrazowanije. Diemokratija, ENWILA, Mińsk.

Prawitielstwo Bietarusi i PROON budut wmiestie borot'sja s biednost'ju (www.naviny.by).

Prokofyeva Natalia, 2003, Poverty in Belarus: Paradoxes of the Post-Soviet Wonderland (http://newsletter.iatp.by/ctr6-8.htm).

Rapieckaja S., 2003, Żenszcziny i biednost', w: Żenszczina. Obrazowanije. Diemokratija, ENWILA, Mińsk.

Sen Amartya, 2000, Nierówności. Dalsze rozważania, tłum. Irena Topińska, Maciej Kochanowicz (współprac.), Znak, Kraków.

Serzhan A., 2004, Wysze i niże waterlinii, „Narodnaja Wola”, 10 lipca.

Shavel Sergej, 1998, Socialnaja politika, w: Sergej Shavel, Anatolij Rubanov, Rozalia Smirnova, Socialnaja struktura, mobilnost', idientifikacija, Mińsk.

Shevchenko S. V., Solodovnikova N. N., 2000, Dinamika dochodow nasielenija i urowen' biednosti w Riespublikie Biełarus’, «Trudy bel.gos.techn. uniwiersiteta», z. VIII: Ekonomika i uprawlenije, Mińsk.

Titarenko Larisa, 2005, Belarus: Values, Fears and Hopes in the Period of Transformation (www.intas.be).

UNISEF, 1995, Children and Women of Belarus. Today and Tomorrow, CEE/CIS and Baltic States Section, Minsk.

Wordsworth Daniel, McPeak Mark, Feeny Thomas, 2005, Understanding Chidren's Experience of Poverty: An Introduction to the DAVE Framework, Christian Children's Fund.

Biełoruskij Rynok - Biełorusy i Rynok (http://www.br.minsk.by). Internetowe archiwum medialne Białorusi (http://bymedia.net).

Narodnaja Wola ( http://nv.promedia.by). 
Sowietskaja Biełarus' — Biełarus' Siegodnia (http://www.sb.by).

ONZ, Ekonomika i obszczestwo Biełarusi: disproporcii i pierspiektiwy razwitija. 2004-2005 (http://un.by/pdf/1321_rus_.pdf).

ONZ, Projekt nacionalnoj strategii priedotwraszczenija biednosti w Biełarusi. 2003-2006 (http://un.by/ru/undp/db/00011744.html).

Narodowy Komitet Statystyczny Białorusi. Badanie gospodarstw domowych (http:// belstat.gov.by/homep/ru/indicators/house.php).

Socialno-ekonomiczeskoje położenije domasznich choziajstw. Statisticzeskij sbornik, Ministierstwo statistiki i analiza, Mińsk 2002.

Socialno-ekonomiczeskoje położenije domasznich choziajstw. Statisticzeskij sbornik, Ministierstwo statistiki i analiza, Mińsk 2001.

Ustawodawstwo na temat budżetu minimum spożycia na Białorusi dostępne on-line: http://www.pravo.by/webnpa/text.asp?RN=c20501016\#3аг_Утв_1, a także http://www.mintrud.gov.by/ru/socnorm/norm1

Zakon o prożitocznom minimumie w Riespublikie Bietarus' z dnia 6.01.1999, "Zwiazda», 28 stycznia 1999.

Zakon Riespubliki Bielarus' o formirowanii i ispolzowanii minimalnogo potriebitielskogo biudżeta z dnia 9 stycznia 1992, „Wiedomosti Wierchownogo Sowieta Riespubliki Biełarus””, 1992, nr 5.

\section{SOME REFLECTIONS ON POVERTY IN BELARUS AS SEEN \\ IN THE ACADEMIC AND NEWSPAPER DISCOURSES}

\section{Summary}

Academic and newspaper discourses on poverty issues in Belarus are discussed in this article. The academic discourse involves poverty statistics and relevant publications by Belarusian sociologists, economists and other researchers from government, non-government and international institutions. The newspaper discourse includes government and non-government newspapers. The goal of this article is to show the essence and forms of poverty in Belarus searching for its visible and latent aspects as well as discursive practices.

\section{Key words/słowa kluczowe}

Belarus / Białoruś; poverty / bieda; academic discourse / dyskurs akademicki; newspaper discourse / dyskurs prasowy; government and non-government institutions / instytucje państwowe i niepaństwowe 